\title{
PENERAPAN LOCATION BASED SERVICE PADA JURUSAN TEKNIK INFORMATIKA FAKULTAS TEKNIK UNIVERSITAS PALANGKA RAYA
}

\author{
Viktor Handrianus Pranatawijaya $^{\text {a,1,* }}$, Deddy Ronaldo ${ }^{\text {b,2 }}$, Farhani ${ }^{c, 3}$ \\ ${ }^{a}$ Universitas Palangka Raya, Jl. H. Timang \\ ${ }^{\mathrm{b}}$ Universitas Palangka Raya, Jl. H. Timang \\ ${ }^{\text {c } U n i v e r s i t a s ~ P a l a n g k a ~ R a y a, ~ J l . ~ H . ~ T i m a n g ~}$ \\ viktorhp@upr.ac.id ${ }^{*} ;{ }^{2}$ deddy.ronaldo@gmail.com; ${ }^{3}$ arhani@mhs.it.upr.ac.id \\ * corresponding author
}

ARTICLE INFO

Keywords

Location Based Service (LBS)

Google Maps API

\begin{abstract}
The campus is one place where the student's education to develop the potential that existed to give birth to students who are creative, crisis, responsible and moral, especially for students. One of the utilization of technology that is now widely used is android.One of them features Android LBS (Location Based Service) is one of the android features used to describe the technology used to find the location of the device that the user by utilizing satellite facilities. One of the problems of the students is the lack of information about the room at Informatics Engineering, University of Palangkaraya which relates to the subjects in Informatics Engineering. By utilizing the feature LBS (Location Based Service) on android will answer the existing problems so as to facilitate students Engineering University of Palangka Raya.

The methodology used in development with Prototype According to Pressman. The programming languages used are Java, JSON, SQLite. Application of Space Presentation Faculty of Engineering, University of Palangkaraya Based Location Based Service is designed and built using a Prototype Pressman method, with map plan designed through Google Earth Pro and Edraw Max 7 which is placed on Google Map API where data storage is made in online database Firebase and SQLite as local database with the development of the application created using Android Studio.
\end{abstract}

\section{Pendahuluan}

Perkembangan teknologi mengalami perkembangan di berbagai bidang pada kalangan masyarakat. Penggunaan teknologi tersebut jugadapat membantu memudahkan kehidupan di kampus.Salah satu pemanfaatan teknologi pada kampus dapat digunakan untuk pengenalan kampus ke mahasiswa dan memudahkan proses pembelajaran.

Jurusan Teknik Informatika merupakan jurusan pada Fakultas Teknik Universitas Palangka Raya. Informasi mengenai jurusan tersebut dapat diakses melalui buku panduan ataupun mendatangi langsung tempat tersebut. Informasi-informasi mengenai ruangan beserta aktifitas dan orang-orang yang terdapat di dalamnya dapat dilakukan dengan mendatangi tempat tersebut dan menyesuaikan dengan data-data jadwal ataupun hal yang terlihat langsung.

Salah satu pemanfaatan teknologi yang sekarang banyak digunakan adalah platformandroid. Banyaknya kalangan yang menggunakan android dari kalangan atas, kalangan bawah dan kalangan menengah menjadi sesuatu kebutuhan sehari-hari yang patut dipertimbangkan untuk mendapatkan informasi. Android memiliki bermacam-macam fitur diantaranya seperti kamera, internet, MMS, Global Positioning System (GPS) termasuk teknologi LBS (Location Based Service) dan lain-lainnya. 
LBS merupakan salah satu fitur android yang digunakan untuk menggambarkan teknologi yang digunakan untuk menemukan lokasi perangkat yang pengguna gunakan dengan memanfaatkan fasilitas satelit. Unsur utama dalam penggunaan LBS (Location Based Service) yakni Location Manager untuk menyediakan fasilitas untuk menampilkan peta dan Location Providers untuk pencarian lokasi yang digunakan oleh perangkat.

LBS adalah sebuah layanan informasi yang dapat diakses dengan perangkat bergerak melalui jaringan dan mampu menampilkan posisi secara geografis keberadaan perangkat bergerak tersebut. LBS dapat berfungsi sebagai layanan untuk mengidentifikasi lokasi dari seseorang atau suatu objek tertentu. Hal paling penting dari LBS dapat bekerja sesuai yang diinginkan oleh pengembang aplikasi Android. Androidpun memungkinkan pengembang menentukan metode pencarian lokasi yang dibutuhkan dan juga dapat mengatur kebutuhan daya, biaya dan akurasi berdasarkan spesifik yang akan dibuat untuk aplikasi tersebut.

Dua unsur utama dari Location Based Service adalah:

a. Location Manager (API Maps): Menyediakan perangkat bagi sumber atau source untuk LBS, Application Programming Interface (API) Maps menyediakan fasilitas untuk menampilkan atau memanipulasi peta. Paket ini berada pada "com.google.android.maps;".

b. Location Providers (API Location): Menyediakan teknologi pencarian lokasi yang digunakan oleh perangkat. API Location berhubungan dengan data GPS dan data lokasi real-time. API Location berada pada paket Android yaitu dalam paket "android.location". Lokasi, perpindahan, serta kedekatan dengan lokasi tertentu dapat ditentukan melalui Location Manager.

Pencarian lokasi ruangan pun dilakukan dengan melihat tanda ruangan tersebut. Seiring dengan perkembangan layanan Teknologi Informasi (TI) yang ada maka untuk melakukan hal tersebut di atas dapat dilakukan dengan menggunakan layanan dari LBS. LBS adalah layanan TI untuk memberikan informasi yang telah dibuat, disusun, dipilih, atau disaring dengan mempertimbangkan lokasi saat ini pengguna atau orang lain atau perangkat mobile (K"upper, 2005).

Semenjak jaringan wireless memungkinkan infrastruktur baru untuk layanan mobile, LBS untuk pengguna ponsel dapat mencari dan mengukur posisi pengguna untuk menyediakan kinerja layanan yang lebih baik (C.-W. Jeong dkk, 2006). Oleh karena itu, LBS sangat membutuhkan pemetaan sistem informasi, bersama dengan layanan Geographic Information System (GIS).

LBS berisi sejumlah komponen termasuk informasi peta dan GIS, layanan penentuan lokasi, dan LBS subkomponen-aplikasi tertentu (Amit Kushwaha, 2011). lain:

Terdapat lima komponen pendukung utama dalam teknologi LayananBerbasis Lokasi, antara

1. Piranti Mobile, adalah salah satu komponen penting dalam LBS. Piranti ini berfungsi sebagai alat bantu (tool) bagi pengguna untuk meminta informasi. Hasil dari informasi yang diminta dapat berupa teks, suara, gambar dan lain sebagainya. Piranti mobile yang dapat digunakan bias berupa PDA, smartphone, laptop. Selain itu, piranti mobile dapat juga berfungsi sebagai alat navigasi di kendaraan seperti halnya alat navigasi berbasis GPS.

2. Jaringan Komunikasi, Komponen ini berfungsi sebagai jalur penghubung yang dapat mengirimkan data-data yang dikirim oleh pengguna dari piranti mobile-nya untuk kemudian dikirimkan ke penyedia layanan dan kemudian hasil permintaan tersebut dikirimkan kembali oleh penyedia layanan kepada pengguna.

3. Komponen Positioning (Penunjuk Posisi/Lokasi), Setiap layanan yang diberikan oleh penyedia layanan biasanya akan berdasarkan pada posisi pengguna yang meminta layanan tersebut. Oleh karena itu diperlukan komponen yang berfungsi sebagai pengolah/pemroses yang akan menentukan posisi pengguna layanan saat itu. Posisi pengguna tersebut bisa didapatkan melalui jaringan komunikasi mobile atau juga menggunakan Global Positioning System (GPS).

4. Penyedia layanan dan aplikasi, merupakan komponen LBS yang memberikan berbagai macam layanan yang bisa digunakan oleh pengguna. Sebagai contoh ketika pengguna meminta layanan agar bias tahu posisinya saat itu, maka aplikasi dan penyedia layanan langsung memproses permintaan tersebut, mulai dari menghitung dan menentukan posisi pengguna, menemukan rute 
jalan, mencari data di Yellow Pages sesuai dengan permintaan, dan masih banyak lagi yang lainnya.

5. Penyedia data dan konten, Penyedia layanan tidak selalu menyimpan seluruh data dan informasi yang diolahnya. Karena bisa jadi berbagai macam data dan informasi yang diolah tersebut berasal dari pengembang/pihak ketiga yang memang memiliki otoritas untuk menyimpannya. Sebagai contoh basis data geografis dan lokasi bisa saja berasal dari badan-badan milik pemerintah atau juga data-data perusahaan/bisnis/industri bisa saja berasal dari Yellow Pages, maupun perusahaan penyedia data lainnya.

Dengan berkembangnya bahasa pemrograman maka GIS pun dapat menjadi lebih interaktif karena pengguna dapat melihat detil suatu tempat beserta informasi mengenai tempat tersebut pada peta. Aplikasi yang dapat dilihat dan berjalan yang menyajikan peta online pun ikut berkembang, salah satunya adalah Google Maps. Peta dibuat dengan memanfatkaan layanan dari Google Map Application Programming Interface (API).

Hal lain yang akan dimanfaatkan pada LBS adalah penggunaan dari untuk penentuan lokasinya. Penggunaan GPS pada LBS pun dimungkinkan dilakukan karena perangkat mobile sekarang biasanya sudah memiliki layanan GPS.

Menurut Allan Brimicombe dan Chao Li pada tahun 2009 LBS adalah pengiriman data dan layanan informasi dimana isi dari layanan tersebut disesuaikan dengan saat ini atau beberapa lokasi yang diproyeksikan dan konteks pengguna mobile. LBS didasarkan pada tiga kategori lokasi yaitu lokasi deskripsi, spatial, dan jaringan (K"upper, 2005).

Peta (Clark, 2003) merupakan representasi dari permukaan bumi atau bagian dari permukaan bumi pada kertas atau media lainnya. Letak atau pun bentuk geografis dari suatu lokasi tertentu merupakan informasi yang terdapat dalam peta. Peta yang disimpan dalam media digital dapat disebut sebagai peta digital.

Bentuk peta digital yang paling sederhana adalah memindahkan media peta yang sebelumnya kertas menjadi gambar pada computer. Dengan peta digital, informasi mengenai bumi tidak terbatas sampai dua dimensi. Dapat dilakukan eksplorasi permukaan bumi hingga keadaan ruang dalam bentuk tiga dimensi. Informasi ruang mengenai bumi sebenarnya sangat kompleks, disinilah peta digital berjaya dengan dapat menunjukkan aspek-aspek berikut pada peta:

1. Lokasi-lokasi yang berkenaan dengan ruang; merupakan objek-objek ruang yang khas pada sistem koordinat (projeksi sebuah peta)

2. Atribut; informasi yang menerangkan mengenai objek-objek ruang yang diperlukan

3. Hubungan ruang; hubungan antar objek-objek ruang

4. Waktu; untuk perolehan data, data atribut dan ruang

Terdapat tiga informasi umum yang dapat dimasukkan dalam peta digital (MindSites Group, 2012), yaitu: (1) informasi geografis yang merupakan informasi mengenai posisi bentuk-bentuk dari fitur geografis yang spesifik, (2) informasi atribut yang merupakan informasi non grafis mengenai tiap-tiap fitur, dan (3) informasi tampilan yang menjabarkan informasi tampilan fitur pada layar. Berdasarkan hal tersebut maka informasi yang akan diberikan pada peta dapat berupa peta, teks, dan gambar.

Peta dapat diterjemahkan ke dalam bentuk biner yang merupakan representasi dari pixel-pixel gambar. Dari bentuk tersebut, didapat informasi geografis yangmerepresentasikan keadaan sebenarnya. Pada pemetaan digital berbagai macam jenis peta yang diklasifikasikan berdasarkan sifat, macam, dan skaladapat diintegrasikan menjadi satukesatuan. Adapun dalampenggunaannya, pemetaan digital dapat menjadi lebih fleksibel karena banyaknya jumlah informasi yang dimiliki dan mudahnya pengaksesan informasi.

Aplikasi berbasis lokasi adalah salah satu yang paling diantisipasi baru segmen industri mobile. Aplikasi ini baru dapat diaktifkan oleh ponsel yang dilengkapi GPS (Jochen Schiller dan Agne`s Voisard, 2004). GPS adalah sistem penentuan lokasi berdasarkan triangulasi sinyal radio dari satelit yang mengudara (Hassan A. Karimi, 2009). 
Pada umumnya dapat diasumsikan pengguna umumnya memiliki perangkat mobile yang dilengkapi GPS (seperti smartphone) dan digunakan untuk mengumpulkan data peta. GPS terdiri dari tiga segmen (Hassan A. Karimi, 2013): (1) segmen satelit, konstelasi satelit itu sendiri, (2) segmen pengguna, termasuk semua penerima GPS digunakan dalam berbagai aplikasi sipil dan militer, dan (3) segmen kontrol, bertanggung jawab untuk menjaga tepat pengoperasian system

Tujuan penelitian ini adalah menerapkan LBS pada Jurusan Teknik Informatika Fakultas Teknik UNPAR sehingga lokasi ruang dan informasi yang terdapat pada ruang tersebut dapat disajikan.Tujuan penelitian yang bersifat khusus adalah pengembangan rumpun ilmu pengetahuan teknik informatika dalam bidang rekayasa perangkat lunak, sistem informasi dan pemrograman web yaitu LBS yang merupakan pengembangan dari GIS menggunakan Google Maps API dan GPS.

\section{Metode Penelitian}

Model yang digunakan menggunakan metodeprototypemenurut Pressman (2012:50). Berikut merupakan langkah-langkah atau tahapan dalam metode prototype:

a. Komunikasi dan pengumpulan data awal, yaitu analisis terhadap kebutuhan pengguna.

b. Quick design, yaitu tahapan pembuatan design secara umum untuk selanjutnya dikembangkan kembali.

c. Pembentukan prototype, yaitu pembuatan perangkat prototype termasuk pengujian dan penyempurnaan.

d. Evaluasi terhadap prototype, yaitu mengevaluasi prototype dan memperhalus analisis terhadap kebutuhan pengguna.

e. Perbaikan prototype, yaitu pembuatan tipe yang sebenernya berdasarkan hasil dari evaluasi prototype.

f. Produksi akhir, yaitu memproduksi perangkat secara benar sehingga dapat digunakan oleh pengguna

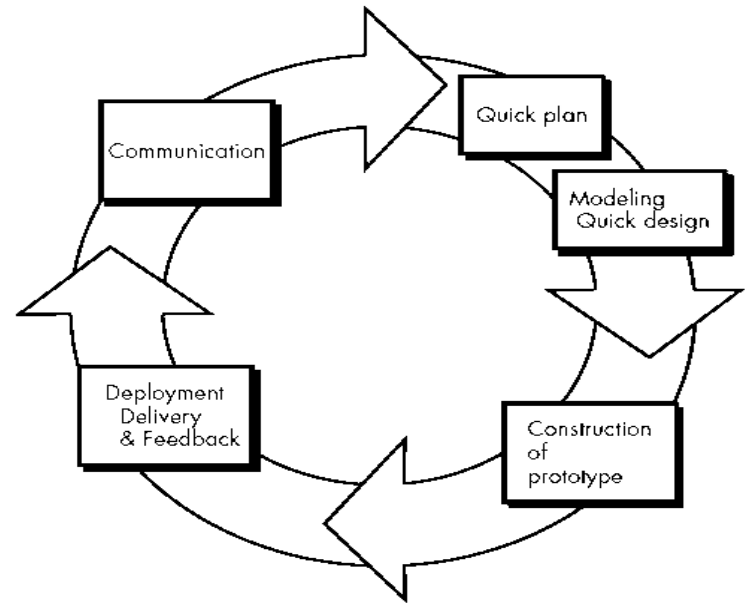

Gambar 1. Prototype (Pressman, 2012)

\section{Hasil dan Pembahasan}

Pengguna dari LBS pada jurusan Teknik Informatika Fakultas Teknik UNPAR yang dibuat terbagi atas tiga hak akses yaitu (1) admin untuk melakukan pengelolaan titik dan informasi titik, pengguna, jadwal perkuliahan dan praktikum, (2) pengguna terdaftar (mahasiswa) untuk melihat titik dan informasi titik, mengelola jadwal perkuliahan dan praktikum pengguna, melakukan check in pada 
titik, mengelola janji, dan memberikan notifikasi dan reminder, dan (3) pengguna tak terdaftar (guest) untuk melihat titik dan informasi titik dan mendaftar pada sistem.

Seorang mahasiswa dan guest membuka sistem dengan smartphone dan masuk ke fitur map. Smartphone akan merequest Google Map API, kemudian Google Map API akan merespond dengan memberikan map. Selanjutnya smartphone yang menggambarkan denah ruangan Jurusan Teknik Informatika Fakultas Teknik Informatika yang denah sudah berada dalam sistem yang dibuat dari aplikasi Google Earth Pro dan dibantu dengan menempatkan marker titik ruangan yang datanya diambil dari firebase untuk menggambarkan titik ruangan beserta radius dari geofence.

Ketika mahasiswa dan guest ini di lingkungan Jurusan Teknik Informatika Fakultas Teknik dan menggunakan smartphonedengan fungsi GPS telah diaktifkan, maka posisi pengguna akan didapatkan dan diperoleh dari Positioning Service. Setelah itu smartphonepengguna mengirimkan permintaan informasi, yang berisi tujuan untuk mencari dan mengirimkan posisi melalui jaringan komunikasi ke gateway telekomunikasi.

Kemudian dengan membaca permintaan dan mengaktifkan layanan yang terkait. Kemudian, servicememberikan informasi mengenai posisi mahasiswa ketika mahasiswa dan guest memasuki $75 \%$ atau $85 \%$ dari kedalam radius titik ruangan di map, maka sistem akan menampilkan notifikasi bahwa mahasiswa dan guest memasuki radius dari ruangan tersebut dengan menampilkan nama ruangannya beserta informasinya yang datanya diakses dari firebase.

Mahasiswa dalam arsitektur sistem disini digambarkan juga dapat melakukan pengelolaan reminder berupa alarm yang dimana datanya yang dikelola berdasarkan data jadwal kuliah yang disimpan dalam firebase kemudian reminder tersebut akan disimpan dalam database lokal SQLite yang nantinya dapat dipanggil secara offline.

Admin disini berperan dalam pengelolaan data-data yang ada di dalam firebase, admin akan selalu memerlukan internet untuk dapat terhubung ke firebase. Admin juga memerlukan Google Map API untuk pengelolaan data ruangan.

LBS pada jurusan Teknik Informatika Fakultas Teknik UNPAR nantinya akan menggunakan sistem operasi Android sehingga penggunaan LBS nantinya dapat dilakukan dengan perangkat mobile. Sebagai salah satu syarat yang harus ada pada perangkat mobile adalah perangkat tersebut memiliki GPS dan menggunakan koneksi internet dalam mengakses informasi-informasi yang ada pada LBS.

Cara mendapatkan informasi pada LBS ini, terbagi atas dua bagian yaitu dengan cara push dan pull. Untuk push dilakukan berada pada lokasi yang sudah ditentukan titiknya dalam radius tertentu dan secara otomatis sistem LBS akan memberikan informasi tanpa harus meminta informasi tersebut. Pada pull informasi diberikan oleh LBS sesuai dengan permintaan pengguna.

Pembuatan LBS pada program nantinya akan menggunakan Google Map API untuk petanya dan perangkat untuk mengakses program tersebut digunakan perangkat mobile yang memiliki GPS dan koneksi internet. Penentuan titik dan radius dilakukan pula ada saat pembuatan program dan menginputkan data titik dan pada basis data.

Use case diagram menggambarkan fungsionalitas yang diharapkan dari sebuah sistem. Adapun use case diagram untuk LBS pada jurusan Teknik Informatika Fakultas Teknik UPR. Aktor yang ada adalah admin, mahasiswa dan guest. 


\section{JURNAL TEKNOLOGI INFORMASI}

[E-ISSN 2656-0321]

[Vol 12. No. 1]

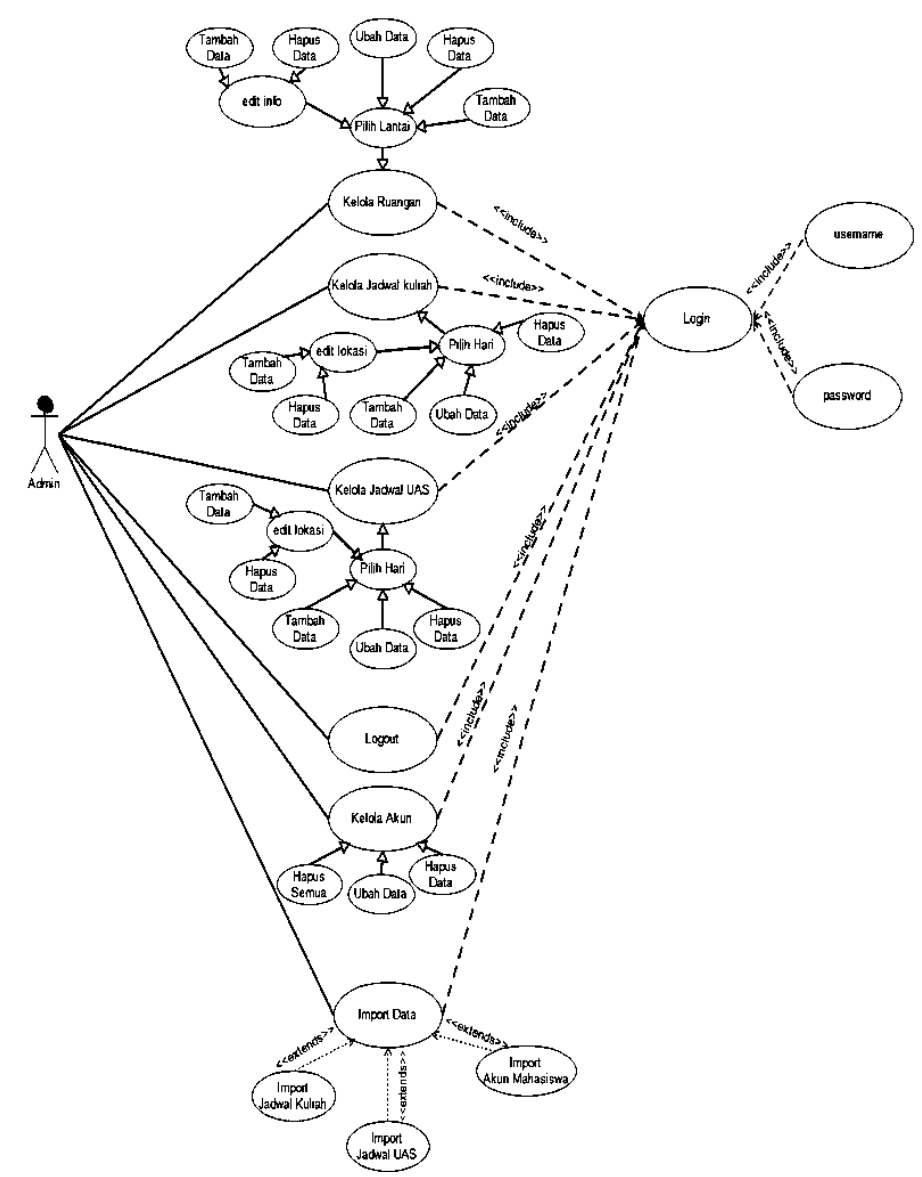

Gambar 2. Use Case Admin

Pada gambar 2 di atas, Admin memilki hak akses keseluruhan sistem yaitu:

1) Admin melakukan Login.

2) Admin mengeloladata :

a. Data ruanganbeserta infonya Teknik Informatika

b. Data jadwal kuliah

c. Data jadwal UAS

d. Data akun

e. Data excel yang diimportkan

3) Admin dapat melakukan log out.

Pada gambar 3 di bawah, merupakan penjelasan dari aktor mahasiswa.Perancangan struktur navigasi dilakukan untuk mempermudah pengguna menjalankan sistem LBS. Untuk melihat perancangan struktur navigasi dapat dilihat pada gambar 4.mahasiswa Jurusan Teknik Informatika yang dapat mengakses aplikasi dengan hak akses adalah:

1. Mahasiswa dapat melakukan login.

2. Mahasiswa melihat jadwal kuliah dan jadwal UAS.

3. Mahasiswa melihat ruangan di map

4. Mahasiswa dapat melakukan perubahan setting aplikasi

5. Mahasiswa menerima notifikasi ruangan

6. Mahasiswa menerima reminder jadwal kuliah dan UAS

7. Mahasiswa dapat mengelola reminder

8. Mahasiswa dapat mengelola akun

9. Mahasiswa dapat melakukan logout. 


\section{JURNAL TEKNOLOGI INFORMASI}

[E-ISSN 2656-0321]

[Vol 12. No. 1]

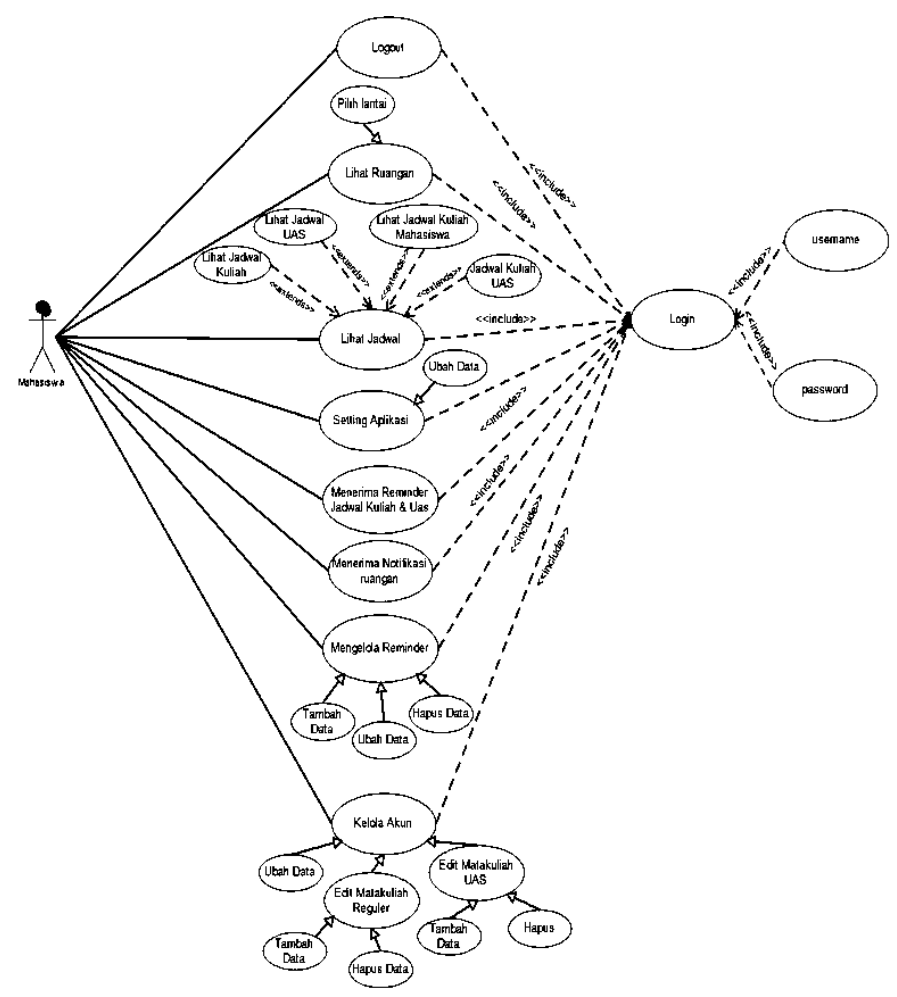

Gambar 3. Use Case Mahasiswa

Aktor guest terlebih dahulu loginsebagai guest sebelum masuk ke dalam sistem, melihat titik serta radius ruangan dengan dilengkapi notifikasi, menerima notifikasi info ruangan ketika mobile yang digunakan untuk menjalankan aplikasi sudah masuk ke dalam radius titik ruangan (gambar 4).

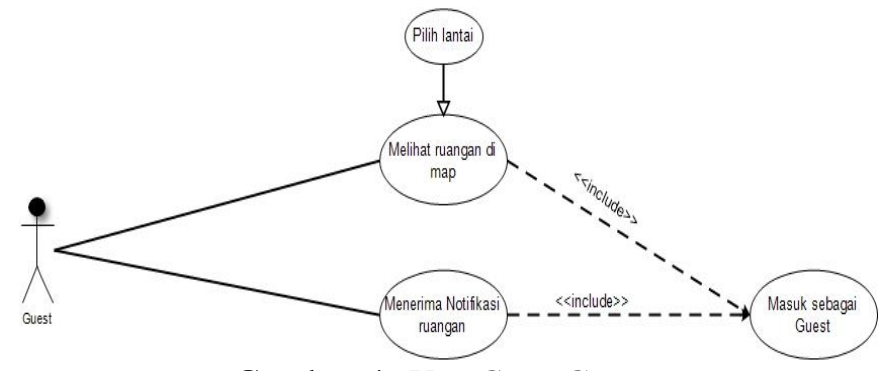

Gambar 4. Use Case Guest

Perancangan antarmuka yang dibuat adalah perancangan desain antarmuka untuk aktor, admin, guest dan juga mahasiswa.

Antarmuka admin, tampilan berandanya (gambar 4) adalah log out, kelola ruangan, jadwal kuliah, jadwal UAS, Kelola Akun, dan Import Data. 


\section{Jurnal Keilmutan dan Aplikasi Bidang Teknik Informatilka}

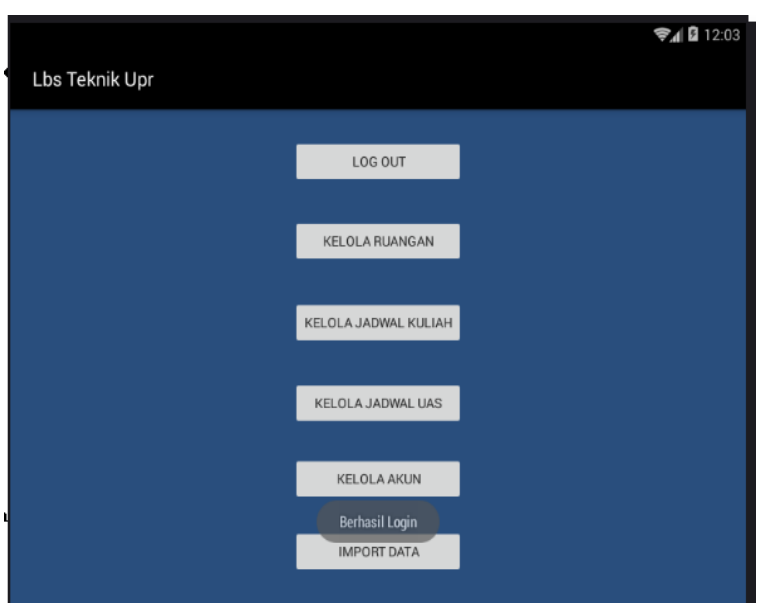

Gambar 5. Beranda Admin

Pada tampilan (gambar 6) kelola ruangan pada lantai 1 dan lantai 2 dimana terdapat inputan ID ruangan, lantai,beserta radius untuk lokasi dan inputan lantai yang dapat ditambah, diubah, dan dihapus datanya untuk dapat dikelola serta dibantu dengan tampilan peta untuk dapat melihat letak titik ruangan.

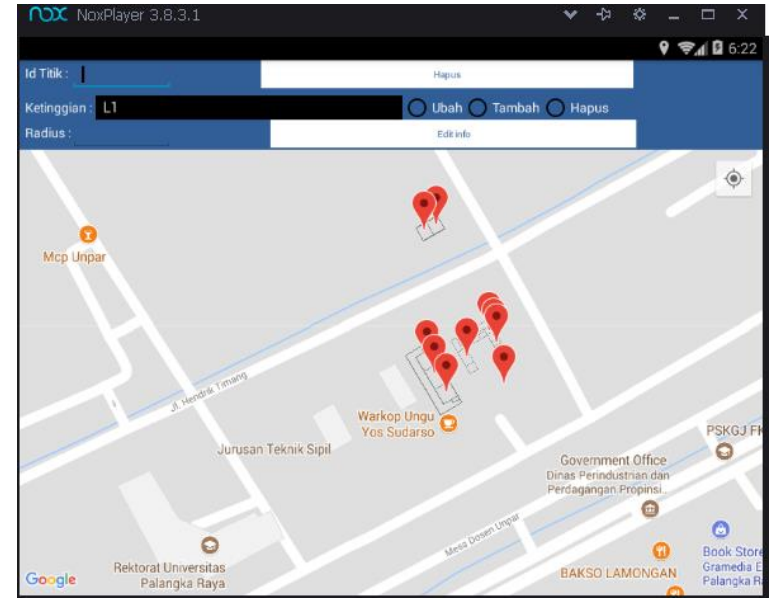

Gambar 6. Kelola Ruangan

Data-data pada sistem dapat diinputkan pada bagian import(gambar 7). Data yang di-import menggunakan file excel dengan format-format yang telah ditentukan. Data-data yang dapat di-import adalah jadwal kuliah, jadwal UAS, dan akun mahasiswa. 


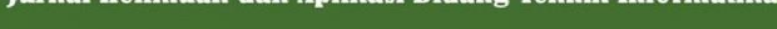

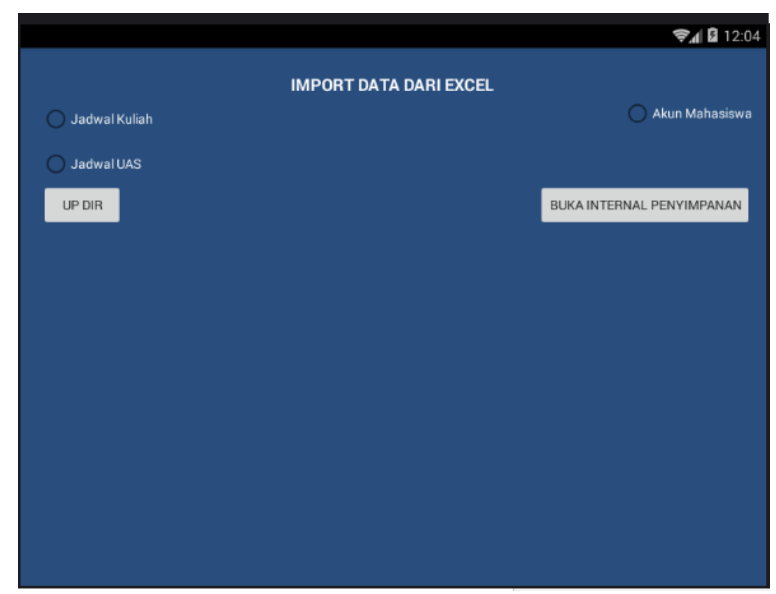

Gambar 7. Import Data

Tampilan pada beranda mahasiswa adalah akun, lihat map, reminder, lihat jadwal, setting, dan log out. Gambar dapat dilihat pada gambar 8. Pada tampilan lihat ruangan dimana mahasiswa dapat melihat titik-titik ruangan beserta denah, radius titik notifikasi dapat dilihat pada gambar 9.Tampilan notifkasi info ruangan dapat dilihat pada gambar 10.

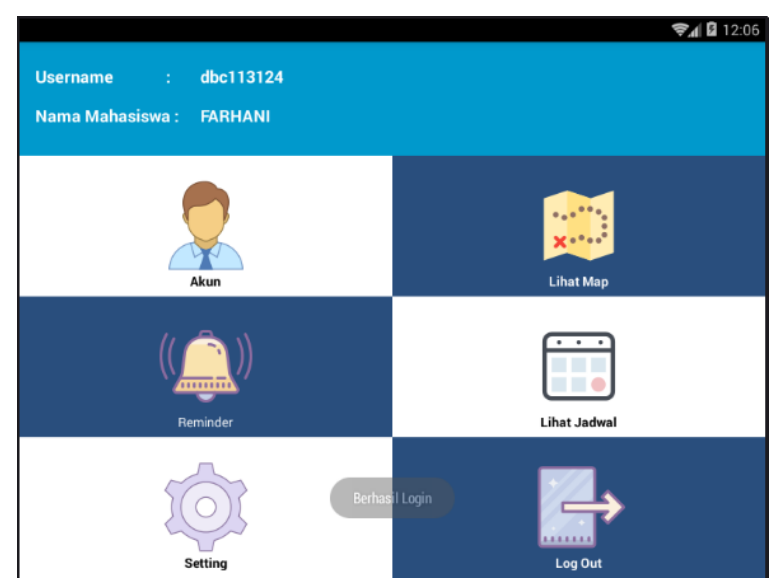

Gambar 8. Beranda Mahasiswa 


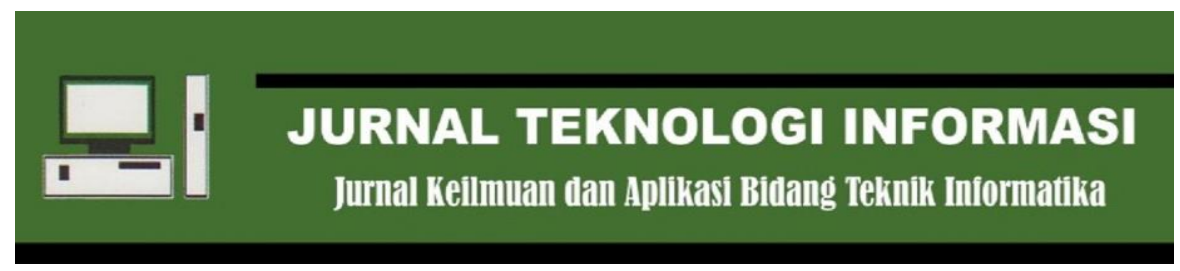

[E-ISSN 2656-0321]

[Vol 12. No. 1]

[Januari 2018]

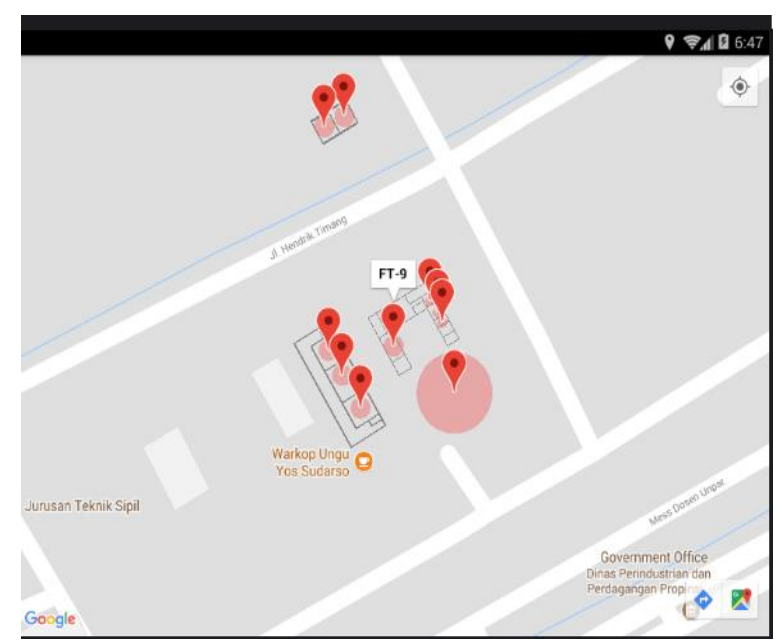

Gambar 9. Tampilan Ruangan

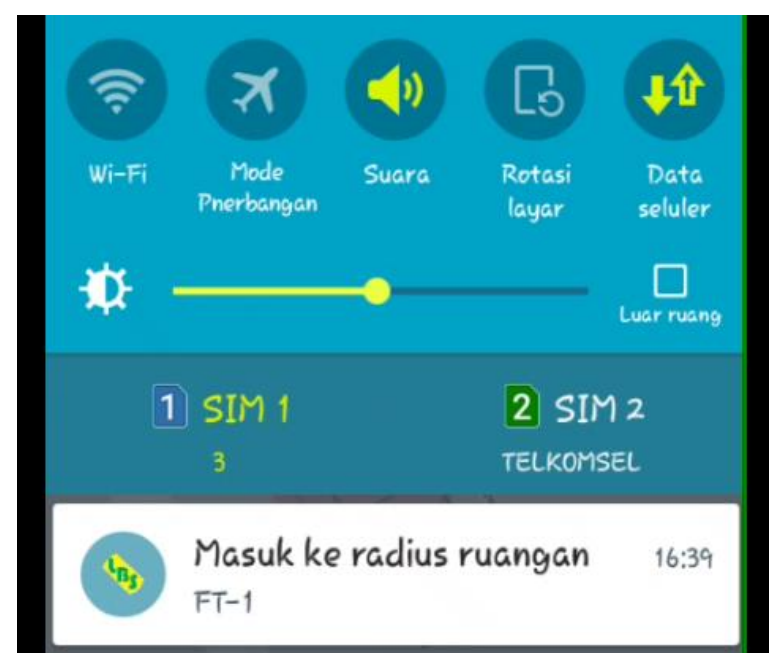

Gambar 10. Tampilan Notifikasi

Pada tampilan reminder akan muncul notifikasi juga untuk mengingatkan jadwal matakuliah mahasiswa tersebut. Untuk ruangan dan notifikasi ruangan untuk aktor guest pada dasarnya sama dengan aktor mahasiswa.

\section{Kesimpulan}

4.1 Kesimpulan yang didapat dari penelitian ini adalah sebagai berikut:

Penerapan LBS pada Jurusan Teknik Informatika Fakultas Teknik Universitas Palangka Rayadibuat dengan menggunakan metodePrototype yang memiliki tahapan komunikasi dan pengumpulan data awal, quick design, pembentukan prototype, evaluasi terhadap prototype, perbaikan prototype, dan produksi akhir.

Penerapan Location Based Service pada Aplikasi Penyajian Ruang Fakultas Teknik Universitas Palangka Raya Berbasis Location Based Service, yakniditerapkan pada Google Map API dengan tiap titik ruangan dibuat marker yang menghasilkan radius-radius yang beragam dimana apabila pengguna aplikasi masuk ke dalam tiap radius itu akan menghasilkan notifikasi informasi ruangan yang berisikan matakuliah yang berada dalam ruangan tersebut sehingga ruang-ruangan yang berhubungan perkuliahan dapat diketahui. 


\section{JURNAL TEKNOLOGI INFORMASI}

[E-ISSN 2656-0321]

[Vol 12. No. 1]

Jurnal Keilmutan dan Aplikasi Bidang Teknik Informatilka

\subsection{Saran}

Saran yang dapat diberikan dari penelitian ini adalah data-data non spasial yang diperlukan oleh sistem dapat dihubungkan dengan sistem informasi akademik yang ada sehingga tidak memerlukan import data lagi. Sistem monitoring pengguna aplikasi juga dapat dibuat sehingga lokasi pengguna pun dapat dilihat di sistem

Demikianlah kesimpulan dan saran pada penelitian ini. Semoga laporan hasil penelitian ini dapat bermanfaat.

\section{Daftar Pustaka}

[1] Allan Brimicombe dan Chao Li. 2009. Location-Based Services and Geo-Information Engineering. John Wiley \& Sons, Ltd

[2] Amit Kushwaha, Vineet Kushwaha. 2011. Location Based Services using Android Mobile Operating System International Journal of Advances in Engineering \& Technology, Mar 2011. IJAET ISSN: 2231-1963 14 Vol. 1,Issue 1,pp.14-20

[3] Clark, Audrey. 2003. Map. Penguin Dictionary of Geography 3d ed Page 247. London: Penguin books.

[4] Hassan A. Karimi. 2009. Handbook of Research on Geoinformatics. IGI Global.

[5] Hassan A. Karimi. 2013. AdvAnced LocAtion-BAsed technoLogies And services.Taylor\& Francis Group, LLC.

[6] Jochen Schiller dan Agne`s Voisard. 2004. Location-Based Services. Morgan Kaufmann Publishers.

[7] K"upper, Axel. 2005. Location-based Services. Fundamentals and Operation. John Wiley \& Sons Ltd, The Atrium, Southern Gate, Chichester,West Sussex PO19 8SQ, England.

[8] Pressman, 2010.Software Engineering : A Practitioner's Approach, 7th ed.Mc Grow Hill. 